\title{
The Four Winds A Portrait of
}

\author{
Diana Tegenkamp
}

\begin{abstract}
Diana Tegenkamp est intéressée à ce qui se trouve "au-delà du cadre," ce "moment de possibilité absolue" qui repose "au-delà de son bord doré." Dans "Un portrait de," tout se fond en une masse floue de "diamants rouges" et de "rectangles opalins," une sensualité puissante qui excède la tyrannie du cadre. Une telle frénésie des sens est présentée comme ce qui résiste à la représentation et démontre une sensibilité féminine rebelle au travail. Cette préoccupation avec le cadre et le cadrage est aussi présente dans "Les quatre vents," où le vertige est créé par le fait de "s'incliner sur un trépied pivotant," et produit un "cadre mal interprété." La prolifération du détail dans chaque pièce parle de l'insuffisance du cadre, et de l'impossibilité de capter complètement.
\end{abstract}

\section{The Four Winds}

Tilting on tripod pivot her view his head fallen just 'so' to catch a certain light through slatted wood. Frame misconstrued, accommodates less a factor of $\mathrm{g}(\mathrm{r})$ azing than creates the misrecognition of her drama, blue glass erasure of. Eventually she did feel herself grow to dislike picture shape of slow motion strides on floor in which objectification was the thing permitted. In the sense that a man and a movie camera can do such things in combination so as to become a sitcom. Over coffee once when their paths had crossed certainly they were politely speaking over the toes of her boots. Tough mistress, though

'."'passive. 
Two drawings.

One, the lines of the body loose and easy the lovers wrapped round one another. The other, a fierce and pre-determined pencil sketch, 'turtle skirt,' fashion model. This move from naive fearlessness to an only somewhat more informed, hence tender, withdrawal inward in which armour is worn so as to not attract attention but to be beautiful.

Speck of dust floats alarming and still comfortable.

Magazines piled on the kitchen table. All such manner of matter decreases, there are options and such limitations about these relations. As in "getting to know" more and more machine-flowers. Conoidal bullet. Detonation point of fulminates and threshold of spin, a body which stops spreading only when it hits the pavement. So that falling in love, she thinks, can really ever only be being in the same place at the same time.

Sunday, 10:35 a.m. The renovations begin. Again.

Q.E.D. A dog's barking is repetitious. Coughing. So much clinking of a stuck elevator door is repetitious. So much clinking of a spoon. A mobile home or at the very least flight and restlessness. When the woman fell over, unraveled. Skeins of, her skin breathtaking vector shattered the plain brown road. Sentences occupational hazard makes the caretaker cry out of sheer ravaged anger. Arm becomes conscious as the eye drifts. Little red lamp and smiling childhood face. The stem of the book, trickling. Territorial, he sprints forward, to find:

some space, but only in movement. Feminism, in fact, does not exist in France.

A body is precisely this increase in the nonsingular points. On a night this creature lay in her bed it was good to do so. 


\section{A Portrait of}

Scent and stray hairs. Rain against wrinkled skin, running in rivulets through the ridges, the umbrella forgotten. The solidity of a foot in a running shoe, crossed over the ankle. A bag of groceries gathered up to one's chest. Small gestures which protect and define. Women locking eyes, reflections in the glass as the train pulls into the next station, overlaid against a black-and-white photograph of a model in white cotton underwear. Merging, the blur of the train's movement kaleidoscope, red diamonds, opal rectangles, adamantine pears, blue eyes. There's a light that has to dawn. I can't explain it, but I know it's there. I'm not afraid, you know. When afternoon light deepens and shadows thicken, when the air crystallizes, and her body shifts into slow motion, running through the clearing and up the snow-covered walkway towards the house, the pleats of the long skirt, up the snow-covered steps, her hand on the door latch, the room inside glowing orange from the fireplace, finding the door locked, and turning, turning around and looking. Beyond the frame. Beyond its gilded edge. That moment of absolute possibility. 